Pakistan Journal of Humanities and Social Sciences

Jan - June 2017, Volume 5, No. 1, Pages 36 - 60

\title{
Productivity and Externality Effects of Exports: An Application of FEDER Model in Pakistan and India
}

\author{
Fatima Subhani ${ }^{1}$, Atif Yaseen ${ }^{2}$, Bashir Ahemd Khan ${ }^{3}$, Anees Ayyub ${ }^{4}$ \\ ${ }^{1}$ COMSATS institute of information Technology, Vehari Campus \\ Email: samarfatima.fs3@gmail.com \\ ${ }^{2}$ PMAS-Arid Agriculture University Rawalpindi, Pakistan \\ Email: atifyaseen717@gmail.com \\ ${ }^{3}$ Lecturer PMAS-Arid Agriculture University Rawalpindi, Pakistan \\ Email: bashirak2002@yahoo.com \\ ${ }^{4}$ Quaid-i-Azam University Islamabad, Pakistan \\ Email: aneesayyub@gmail.com
}

\begin{abstract}
To find out export led growth (ELG), this look at has used FEDER model to seize the deliverside effects for Pakistan and India. In FEDER model, this look at has used sectors to discover general consequences of export zone on increase via applying the OLS method. The hypothesis that marginal elements productivities are not identical in export and non-export sectors of the Pakistan and India economy is tested through the usage of the time series facts 1972 to 2014. In FEDER version, the full results of exports together with externality effects and productiveness differential have been re-expected. The predicted effects indicate that marginal aspect productivities are significantly better in export region in case of Pakistan simplest. Moreover the distinction appears to derive, in part, from inter-sectoral advantageous externalities generated by export zone. The effects of productivity differential of export zone appear with bad sign in the course of the evaluation for Pakistan however it is advantageous for India. In broad terms, therefore the consequences of this examine are within the aid of export orientated, outward looking coverage to trade family members adopted with the aid of policymakers during the last a long time.
\end{abstract}

Keywords: Gross Domestic Product, Export led growth, OLS technique, Marginal productivities, Externality effect, Productivity differential

\section{Introduction}

Export plays a vital role to enhance economic growth. Export is considered as an engine of growth. Many empirical studies have been made to understand the importance of 
exports. It goes back to classical theories represented by Adam Smith and Ricardo. Major purpose of theories was to clarify the importance of exports on economic growth and there are the benefits from specialization. Export is the part of national income and it has direct relationship with gross domestic product (GDP). It has also impact on balance of payments and employment level in an economy. Minimum transport costs, globalization, economies of scale, reduced tariff barriers, transformation of new ideas and innovation of new technology have made the export as an important and bigger share of national income of a country. Export growth for the economic growth of Pakistan and India is very essential. Export is nothing but transformation of goods, services, new ideas, technology and machinery etc. So it has a remarkable value in economic growth of Pakistan and India to achieve the macroeconomic goals. [Feder (1982), Khan Et.al (1995)].

The world has become a global village and a nation is passing through this era of globalization. Many countries depend on export to enhance their economic growth and to earn foreign exchange reserve. Export has both the direct and indirect positive impact on economic growth. The indirect impact of exports is economies of scale, high capacity utilization, high marginal productivities in export sector and positive external effect of export sector on nonexport sector. Furthermore, firms that take part in foreign market have access to efficient technology and technical advisor regarding designs and packaging and also have access to new and cheaper production methods. So, countries are moving to adopt the export promotion policies to take the advantage of both the direct and indirect benefits of exports. [Feder (1982), Shan and Tian (1995)].

The relative merits of export promotion and import substitution policies have received substantial value in literature of development. Export is providing the number of opportunities for economies to grow and develop. The past decades have witnessed a rising agreement in favor of export promotion. The world has become a global village and this globalization has brought about fundamental changes on national and international level. The most important unification is word movement towards the export promotion. The role of IMF and World Bank in this respect is remarkable. History of past decades shows that the volume of exports has increased by many folds. The data available on world development indicators, IMF and IFS show the importance of export sector to enhance the GDP- ratio of countries. [Aurangzeb (2006), Siddique and Selvanathan].

The overall performance of export area may be very vital in case of Pakistan and India. each countries are looking to make bigger their export quarter but they are fail to get 
percentage within the global market due to many reasons e.g. less diversification of exports, semifinal items, narrow export base, antique and old technology, devaluation, increment within the variety of sick business devices, trade barriers and political instability and so on. Due to above stated factors Pakistan and India are going through negative performance of export quarter. Despite of lively efforts by way of the authorities of Pakistan and India the export to GDP ratio is identical over time and share in their exports in international market isn't always fantastic. Pakistan and India as growing nations are facing financial challenges. So, export-led increase is a high-quality approach to triumph over the low financial growth in case of Pakistan and India. [Abbas et.al (2015)].

Now this study is going to clear the importance of exports to enhance economic growth in case of Pakistan and India. The key objective of this study is to show the productivity and external effects of exports on economic growth by using the Feder approach in case of Pakistan and India. So both countries can move to the right way to succeed by adopting the export promotion policies like minimizing the trade barriers, availability of finance to promote exports and subsidies given by government to expand the export sector. So that these countries can earn more and more foreign exchange reserves to minimize the pressure of balance of payments (BOP) against imports of both countries. Furthermore, both countries Pakistan and India can easily adopt the export promotion policies to lead to economic growth. [Pandey (2006), Aurangzeb (2006), Sahni and Atri (2012)].

Export is considered as vital pillar of economic growth. It seems to be like as an engine of growth. A sustainable development is associated with exports of a country and foreign reserves earnings from it. All countries that have been adopted the export oriented policies experiencing the high growth rate. Since, the relationship between export and economic growth has been studied by number of people and these empirical studies have proved the significance of export for economic growth. But we are going to show the productivity, external effects of exports on economic growth by the application of Feder model in case of Pakistan and India.[Aurangzeb (2006), Eusuf and Ahmad (2007), Shirazi and Manap (2004)].

The vital purpose of this study is to show the productivity, external effect of export sector on economic growth by using the Feder model in case of Pakistan and India from 1972 to 2014. An attempt has been made to show the relationship of exports and many other variables with economic growth. The study has following main objectives: 
- Export growth has positive impact on economic growth along its productivity differential and external effects in case of Pakistan and India

- Labor force growth also has positive impact on economic growth in case of Pakistan and India.

- Gross fixed capital formation growth also has positive impact on economic growth of Pakistan and India.

The structure of study is as follows: Section two is about literature review of previous studies to support current study. Section three consists of trends and performance of exports in Pakistan and India. In section four, theoretical modeling and empirical specifications are stated. Section five is about data and methodology. Section six consists of results and discussion and section seven represents conclusion and policy recommendations.

\section{Review of Empirical Literature}

This study is intended to predict the importance of productivity, external effect of export on economic growth: an application of Feder model in case of Pakistan and India. Feder model is only a model which predicts both direct and indirect impact of exports on economic growth of a country. Among many other ingredients, exports and productivity are the important ingredients that can impact the economic growth of a country. This section presents review of various studies on export, productivity and economic growth. Table 1 displays the summary of review of various studies based on Feder Model.

\section{Table 1: Summary of Review of Assorted Studies based on Feder Model}

\begin{tabular}{|c|c|c|c|c|c|}
\hline Reference & Country & Data & Model & Methodology & Main Results \\
\hline $\begin{array}{l}\text { Siddique and } \\
\text { Selvanathan }\end{array}$ & Malaysia & $\begin{array}{l}\text { Time series } \\
1966-1996\end{array}$ & $\begin{array}{l}\text { GDP=f(total } \\
\text { exports, } \\
\text { manufactured } \\
\text { exports) }\end{array}$ & $\begin{array}{l}\text { cointegration and } \\
\text { Granger causality }\end{array}$ & $\begin{array}{l}\text { one way causality from } \\
\text { economic growth to } \\
\text { manufactured exports }\end{array}$ \\
\hline $\begin{array}{l}\text { Feder } \\
(1982)\end{array}$ & $\begin{array}{c}\text { Semi } \\
\text { industrialize } \\
\mathrm{d}\end{array}$ & $\begin{array}{l}\text { Panel data } \\
1964-1973\end{array}$ & Feder Model & Panel Least Square & $\begin{array}{l}\text { Positive externality, } \\
\text { Marginal productivities } \\
\text { high in export sector }\end{array}$ \\
\hline $\begin{array}{c}\text { Jung and } \\
\text { Marshall (1985) }\end{array}$ & $\begin{array}{c}37 \\
\text { Developing } \\
\text { countries }\end{array}$ & $\begin{array}{l}\text { Panel data } \\
1950-1981\end{array}$ & $\begin{array}{c}\mathrm{GDP}=\mathrm{f}(\text { real } \\
\text { exports) }\end{array}$ & $\begin{array}{l}\text { Maximum Likelihood } \\
\text { Estimation technique }\end{array}$ & $\begin{array}{l}\text { One way causality } \\
\text { running from exports to } \\
\text { economic growth in } \\
\text { four countries }\end{array}$ \\
\hline $\begin{array}{l}\text { Khan et.al } \\
\text { (1995) }\end{array}$ & Pakistan & $\begin{array}{l}\text { Time series } \\
1972-1994\end{array}$ & $\begin{array}{c}\mathrm{GNP}=\mathrm{f}(\text { exports, } \\
\text { primary exports, } \\
\text { manufactured } \\
\text { exports) }\end{array}$ & $\begin{array}{c}\text { Ordinary Least Square } \\
\text { (OLS) }\end{array}$ & $\begin{array}{c}\text { Feedback relationship } \\
\text { between exports and } \\
\text { economic growth }\end{array}$ \\
\hline $\begin{array}{c}\text { Shan and Tian } \\
\text { (1998) }\end{array}$ & Shanghai & $\begin{array}{c}\text { Time series } \\
1990-1 \text { to } \\
1996-12\end{array}$ & $\begin{array}{l}\mathrm{GDP}=\mathrm{f}(\text { investment, } \\
\text { labor, imports, FDI, } \\
\text { exports) }\end{array}$ & VAR model & $\begin{array}{l}\text { One way causality } \\
\text { running from exports to } \\
\text { economic growth }\end{array}$ \\
\hline $\begin{array}{c}\text { E.M.Ekanaye } \\
\text { (1999) }\end{array}$ & $\begin{array}{c}\text { India, } \\
\text { Indonesia, } \\
\text { Korea, } \\
\text { Malaysia, } \\
\text { Pakistan, }\end{array}$ & $\begin{array}{c}\text { Time series } \\
1960-1997\end{array}$ & $\begin{array}{c}\mathrm{GDP}=\mathrm{f}(\text { real } \\
\text { exports) }\end{array}$ & $\begin{array}{l}\text { Cointegration and } \\
\text { ECM }\end{array}$ & $\begin{array}{c}\text { Feedback relationship } \\
\text { between exports and } \\
\text { economic growth }\end{array}$ \\
\hline
\end{tabular}


Fatima Subhani, Atif Yaseen, Bashir Ahemd Khan, Anees Ayyub

\begin{tabular}{|c|c|c|c|c|c|}
\hline & $\begin{array}{l}\text { Philippine, } \\
\text { Sri Lanka, } \\
\text { and Thailand }\end{array}$ & & & & \\
\hline $\begin{array}{l}\text { Awokuse.Titus } \\
\text { (2002) }\end{array}$ & Canada & $\begin{array}{l}\text { Time series } \\
1961-2000\end{array}$ & $\begin{array}{l}\mathrm{GDP}=\mathrm{f}(\text { capital, } \\
\text { labor, exports, term } \\
\text { of trade, foreign } \\
\text { shock to output) }\end{array}$ & VAR and VECM & $\begin{array}{l}\text { Exports to economic } \\
\text { growth causality in both } \\
\text { short run and long run. }\end{array}$ \\
\hline $\begin{array}{c}\text { Shirazi and } \\
\text { Manap (2004) }\end{array}$ & Pakistan & $\begin{array}{l}\text { Time series } \\
1960-2003\end{array}$ & $\begin{array}{l}\mathrm{GDP}=\mathrm{f} \text { (exports, } \\
\text { imports) }\end{array}$ & J.J approach & $\begin{array}{l}\text { Positive relationship } \\
\text { between exports and } \\
\text { economic growth }\end{array}$ \\
\hline $\begin{array}{l}\text { Din.Musleh } \\
\text { (2004) }\end{array}$ & $\begin{array}{c}\text { Bangladesh, } \\
\text { Nepal, } \\
\text { Srilanka, } \\
\text { India, } \\
\text { Pakistan }\end{array}$ & $\begin{array}{l}\text { Time series } \\
1965-2002\end{array}$ & $\begin{array}{c}\mathrm{GDP}=\mathrm{f} \text { (exports, } \\
\text { imports) }\end{array}$ & $\begin{array}{l}\text { Multivariate VAR } \\
\text { framework }\end{array}$ & $\begin{array}{l}\text { Feedback causality } \\
\text { between exports and } \\
\text { economic growth }\end{array}$ \\
\hline $\begin{array}{l}\text { Hameed et.al } \\
\qquad(2005)\end{array}$ & $\begin{array}{l}\text { Bangladesh, } \\
\text { India, } \\
\text { Maldives, } \\
\text { Nepal, } \\
\text { Pakistan and } \\
\text { Sri Lank } \\
\end{array}$ & $\begin{array}{l}\text { Panel data } \\
1973-2003\end{array}$ & Feder Model & Panel Least Square & $\begin{array}{l}\text { Positive relationship } \\
\text { between exports and } \\
\text { economic growth }\end{array}$ \\
\hline $\begin{array}{l}\text { Quddus and } \\
\text { Saeed (2005) }\end{array}$ & Pakistan & $\begin{array}{l}\text { Time series } \\
1970-2004\end{array}$ & $\begin{array}{l}\text { Feder and Sheehy } \\
\text { model }\end{array}$ & Johansen approach & $\begin{array}{l}\text { Positive relationship } \\
\text { between exports and } \\
\text { economic growth }\end{array}$ \\
\hline $\begin{array}{c}\text { Aurangzeb } \\
\text { (2006) }\end{array}$ & Pakistan & $\begin{array}{l}\text { Time series } \\
1973-2005\end{array}$ & Feder Model & OLS & $\begin{array}{l}\text { Positive externality of } \\
\text { export and marginal } \\
\text { productivities high in } \\
\text { export sector }\end{array}$ \\
\hline $\begin{array}{l}\text { Pandey.Alok } \\
\text { (2006) }\end{array}$ & India & $\begin{array}{l}\text { Time series } \\
1950-2002\end{array}$ & $\begin{array}{c}\text { GDP/eight } \\
\text { variants=f(exports) }\end{array}$ & OLS & $\begin{array}{c}\text { ELG and also supports } \\
\text { GLE }\end{array}$ \\
\hline $\begin{array}{c}\text { Eusuf and } \\
\text { Ahmed (2007) }\end{array}$ & $\begin{array}{l}\text { South Asian } \\
\text { countries }\end{array}$ & $\begin{array}{c}\text { Time series } \\
(1995,19992 \\
004,2006)\end{array}$ & $\mathrm{GDP}=\mathrm{f}$ (exports) & $\begin{array}{l}\text { ECM and Engle } \\
\text { Granger Causality }\end{array}$ & $\begin{array}{c}\text { ELG in Srilanka, } \\
\text { Bhuttan and Pakistan } \\
\text { But GLE in India, Nepal } \\
\text { and Maldives }\end{array}$ \\
\hline $\begin{array}{l}\text { Siddiqui et.al } \\
\quad(2008)\end{array}$ & Pakistan & $\begin{array}{l}\text { Time series } \\
1971-2005\end{array}$ & $\begin{array}{l}\mathrm{GDP}=\mathrm{f}(\text { export, } \\
\text { import, labor force, } \\
\text { term of trade) }\end{array}$ & OLS & $\begin{array}{l}\text { Exports, imports and } \\
\text { labor force have } \\
\text { positive impact on } \\
\text { economic growth } \\
\end{array}$ \\
\hline $\begin{array}{l}\text { Mehdi and Reza } \\
\text { (2011) }\end{array}$ & Iran & $\begin{array}{l}\text { Time series } \\
1961-2006\end{array}$ & $\begin{array}{c}\text { GDP }=\mathrm{f}(\text { exports, } \\
\text { employment, } \\
\text { investment) }\end{array}$ & OLS & $\begin{array}{l}\text { Export effect positively } \\
\text { economic growth }\end{array}$ \\
\hline $\begin{array}{l}\text { Sahni and Atri } \\
\text { (2012) }\end{array}$ & India & $\begin{array}{l}\text { Time series } \\
1980-2009\end{array}$ & $\begin{array}{c}\mathrm{GNP}=\mathrm{f}(\text { total } \\
\text { exports, } \\
\text { manufactured } \\
\text { exports, investment) }\end{array}$ & OLS & $\begin{array}{c}\text { Positive impact of all } \\
\text { explanatory variables on } \\
\text { GNP }\end{array}$ \\
\hline $\begin{array}{l}\text { Shihab et.al } \\
\text { (2014) }\end{array}$ & Jordan & $\begin{array}{l}\text { Time series } \\
2000-12\end{array}$ & $\mathrm{GDP}=\mathrm{f}$ (exports) & $\begin{array}{c}\text { Granger Causality \& } \\
\text { Johansan } \\
\text { Cointegration }\end{array}$ & Support GLE \\
\hline $\begin{array}{l}\text { Saleem and Sial } \\
\text { (2015) }\end{array}$ & Pakistan & $\begin{array}{l}\text { Time series } \\
1973-2013\end{array}$ & $\begin{array}{c}\mathrm{GDP}=\mathrm{f}(\text { human } \\
\text { capital, real exports, } \\
\text { GFCF) }\end{array}$ & ARDL Approach & $\begin{array}{l}\text { Two way causality } \\
\text { between exports and } \\
\text { economic growth and } \\
\text { positive relationship } \\
\text { between economic } \\
\text { growth and all variables. }\end{array}$ \\
\hline
\end{tabular}

Source: Authors' compilation

It can be concluded from above mentioned studies that productivity, external effect of export on economic growth is positive. While some of above studies also show negative relationship. These studies proved the incompatible results with authentic logics and reasons. Some empirical studies support export-led growth while some do not support it. A very few 
studies have been made to check the direct and indirect impact of exports and productivity on economic growth by using the Feder model in context of Pakistan and India. Therefore, we are going to examine the relationship between exports, productivity and economic growth; an application of Feder model in case of Pakistan and India.

\section{Trends and Performance of Exports in Pakistan and India}

In this section, we will investigate the trend and performance of export in case of Pakistan and India. Export is nothing but it is transformation of goods and services from one place to another place. It also involves the transformation of technology, new ideas and capital goods etc.

All countries that have adopted the export oriented policies have experienced high economic growth. Marginal productivities of labor, capital and all other inputs indulge in export sector are high than non-export sector. Export promotion policies should be adopted in case of Pakistan and India. This trend will support the export led growth (ELG) in Pakistan and India.

\section{A. Trends of Export in Pakistan and India}

Trends of fluctuation of export in case of Pakistan and India is shown by following given values. Overall average of export in case of Pakistan is 13.57 but in case of India is 11.49. It is clear that the overall average of exports of Pakistan is more than the overall average value of India. The overall variations in exports of Pakistan are 2.26. Similarly, overall variations in exports of India are 6.8. The overall variations in export of India are more than the overall variations in export of Pakistan.

\section{Figure 1: Trends of Exports in Pakistan and India}

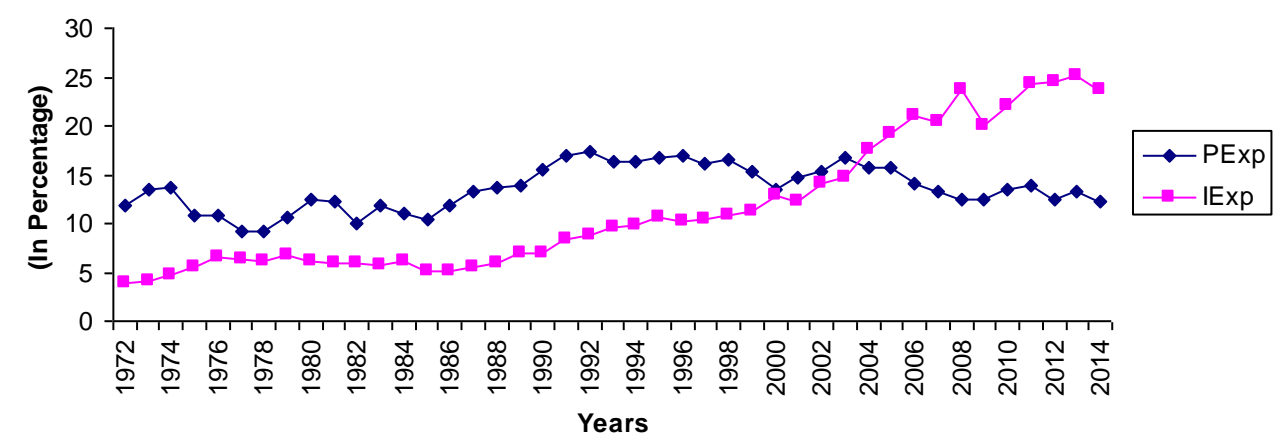

In case of Pakistan, the average export of first decade was 11.45 and variations in first decade were 1.57. Similarly, in case of India the average export of first decade was 5.59 and variations in first decade were 0.97. The average of exports of first decade of Pakistan was higher than the India. Similarly, variations of exports in first decade of Pakistan was high than 
India. The average of exports of first decade of both countries was less than the overall average of exports. The variations in export of first decade of both countries were less than overall variations in export.

In case of Pakistan, the average export of second decade was 12.84 and variations in second decade were 2.24. Similarly, in case of India the average export of second decade was 6.1677 and variations in second decade were 0.98 . The average of exports of second decade of Pakistan was higher than the India. Similarly, variations in exports of second decade of Pakistan were higher than India. The average of exports of second decade of both countries was less than the overall average of exports. The variations in export of second decade of both countries were less than overall variations in export.

In case of Pakistan, the average export of third decade was 15.96 and variations in third decade were 1.17. Similarly, in case of India the average export of third decade was 10.67 and variations in third decade were 1.23. The average of exports of third decade of Pakistan was higher than the India. Similarly, variations in exports of third decade of Pakistan were lower than India. The average of exports of third decade of Pakistan was higher than overall average of exports. But in case of India the average of third decade of exports was lower than overall average of exports. The variations in export of third decade of India were lower than overall variations in export.

In case of Pakistan, the average export of fourth decade was 13.91 and variations in fourth decade were 1.48. Similarly, in case of India the average export of fourth decade was 20.78 and variations in fourth decade were 3.63. The average of exports of fourth decade of Pakistan was lower than the India. Similarly, variations in exports of fourth decade of Pakistan were lower than India. The average of exports of fourth decade of Pakistan was lower than overall average of exports. But in case of India the average of fourth decade of exports was higher than overall average of exports. The variations in export of fourth decade of India were lower than overall variations in export. Similarly, variations in export of fourth decade of Pakistan were lower than overall variations in export.

\section{B. Trends of Economic Growth in Pakistan and India}

Overall mean value of economic growth of Pakistan is 4.83 and variations in economic growth are 2.17. Similarly, overall mean value of economic growth of India is 5.64 and variations in economic growth are 3.04. Overall average value of economic growth for Pakistan is lower than overall mean value of India. Similarly, the variations in economic growth for India are higher than variations in economic growth for Pakistan. 
In case of India the average value of economic growth of first decade was 3.52 and variations were 4.34. Similarly, in Pakistan the average value of first decade of economic growth was 5.47 and variations were 2.79 . The average value of economic growth in first decade for Pakistan was higher than India. The variations in economic growth in first decade for India were higher than Pakistan. The average value in first decade of economic growth was higher than overall mean value in case Pakistan. The average value in first decade of economic growth was lower than overall mean value in case India. The overall variations in economic growth of India were lower than first decade. Similarly, overall variations in economic growth of Pakistan were lower than first decade.

In case of India the average value of economic growth of second decade was 5.08 and variations were 2.31. Similarly, in Pakistan the average value of second decade of economic growth was 6.01 and variations were 1.14. The average value of economic growth in second decade for Pakistan was higher than India. The variations in economic growth in second decade for India were higher than Pakistan. The average value in second decade of economic growth was higher than overall mean value in case Pakistan. The average value in second decade of economic growth was lower than overall mean value in case India. The overall variations in economic growth of India were higher than second decade. Similarly, overall variations in economic growth of Pakistan were higher than second decade.

\section{Figure 2: Trends of Economic Growth in Pakistan and India}

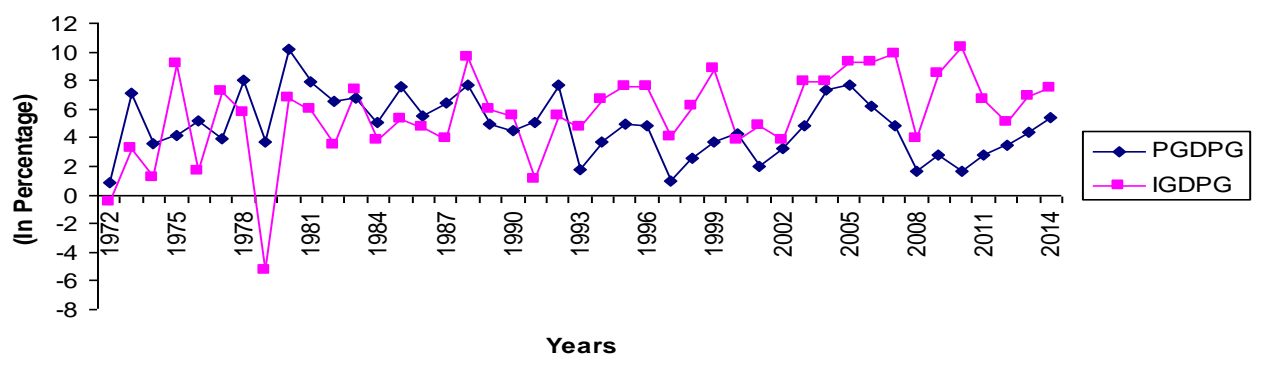

In case of India the average value of economic growth of third decade was 5.98 and variations were 1.68. Similarly, in Pakistan the average value of third decade of economic growth was 3.65 and variations were 1.96. The average value of economic growth in third decade for Pakistan was lower than India. The variations in economic growth in third decade for India were higher than Pakistan. The average value in third decade of economic growth was lower than overall mean value in case Pakistan. The average value in third decade of economic growth was higher than overall mean value in case India. The overall variations in 
economic growth of India were higher than third decade. Similarly, overall variations in economic growth of Pakistan were higher than third decade.

In case of India the average value of economic growth of fourth decade was 7.43 and variations were 2.12. Similarly, in Pakistan the average value of fourth decade of economic growth was 4.33 and variations were 1.98. The average value of economic growth in fourth decade for Pakistan was lower than India. The variations in economic growth in fourth decade for India were higher than Pakistan. The average value in fourth decade of economic growth was lower than overall mean value in case Pakistan. The average value in fourth decade of economic growth was higher than overall mean value in case India. The overall variations in economic growth of India were higher than fourth decade. Similarly, overall variations in economic growth of Pakistan were higher than fourth decade.

By over viewing the above graphs we are able to conclude that trend of export in Pakistan was declining in first two decades but now export has increasing trend. The trend of export in India was decreasing in first decades but now it has increasing trend. Similarly, the trend of economic growth for Pakistan is decreasing but India has increasing trend.

\section{Model Specification}

This section shows the theoretical framework developed by Feder (1982) to study the total effect of exports on economic growth. This total effect is decomposed into two parts; productivity differential and external effect of exports sector on non-export sector. Let assume that total production in the economy $\mathrm{Y}$, be composed of two sectors export sector $(\mathrm{X})$ and non-export sector $(\mathrm{N})$. Instead of national production function, each of the two sectors' output is a function of factors utilizing in each sector. Moreover the non-export sector is dependent on export sector. It means the production of non-export sector is dependent on the volume of export produced. This formulation represents the positive and beneficial effects of export sector on other sectors (non-export sector). So, these beneficial effects can be regarded as positive externalities of export sector on non-export sector. These positive externalities are considered as development of efficient and internationally competitive management, introduction to improve production techniques, latest technical innovation, training of more productive labor, inflow of capital goods from foreign countries etc. But these externalities are not reflected in market prices.

This formulation is given below:

$$
N=F\left(K_{n}, L_{n}, X\right)
$$


As export sector $(\mathrm{X})$ has positive externalities on non-export sector $(\mathrm{N})$. Where $K_{n}$ and $L_{n}$ are the stock of stock of capital and stock of labor in non-export sector respectively, $\mathrm{X}$ is externalities of export sector on non-export sector. Let the output function in export sector is given as below:

$$
X=G\left(K_{x}, L_{x}\right)
$$

Where $K_{x}$ and $L_{x}$ are the stock of capital and labor in export sector respectively. Further it is also assumed that total production in the economy $\mathrm{Y}$, be composed of two sectors export sector $(\mathrm{X})$ and non-export sector $(\mathrm{N})$.

$$
Y=N+X
$$

Factors of production (labor \& capital) use in both sectors are considered as total factors of production being used in an economy:

$$
\begin{aligned}
& K_{T}=K_{n}+K_{x} \\
& L_{T}=L_{n}+L_{x}
\end{aligned}
$$

In addition it is also assumed that factor productivities are different in both sectors. It is assumed that export sector is more productive than non-export sector. As we have already discussed the reasons of more productivity of export sector. Now the marginal productivity of export sector w.r.t. base sector (non-export sector):

$$
\frac{\partial G}{\partial L_{x}}=G_{L} ; \quad \frac{\partial G}{\partial K_{x}}=G_{K}
$$

Similarly:

$$
\frac{\partial F}{\partial L_{n}}=F_{L} ; \quad \frac{\partial F}{\partial K_{n}}=F_{K}
$$

Now suppose the ratio of marginal factor productivities in two sectors deviate from a unity by a factor $\delta$ i.e.

$$
\frac{G_{K}}{F_{K}}=\frac{G_{L}}{F_{L}}=(1+\delta)
$$

It can be written as under:

$$
\left.\begin{array}{rl}
G_{K} & =(1+\delta) F_{K} \\
G_{L} & =(1+\delta) F_{L}
\end{array}\right]
$$

So according to the discussion in previous section it was assumed that $\delta>0$. However the externalities are not included in $\delta$.

Now taking differential w.r.t time of equation (3): 
$\dot{Y}=\dot{N}+\dot{X}$

So we get:

$$
\begin{aligned}
& \dot{N}=\frac{\partial F}{\partial L_{n}}\left(\dot{L}_{n}\right)+\frac{\partial F}{\partial K_{n}}\left(\dot{K}_{n}\right)+\frac{\partial F}{\partial X}(\dot{X}) \\
& \dot{N}=F_{L} \dot{L}_{n}+F_{K} \dot{K}_{n}+F_{x} \dot{X}
\end{aligned}
$$

Similarly,

$$
\begin{aligned}
& \dot{X}=\frac{\partial G}{\partial L_{x}}\left(\dot{L}_{x}\right)+\frac{\partial G}{\partial K_{x}}\left(\dot{K_{x}}\right) \\
& \dot{X}=G_{L} \dot{L}_{x}+G_{K} \dot{K}_{x}
\end{aligned}
$$

It must be assumed that export sector has externalities on non-export sector but nonexport sector has no externalities on export sector. It is assumed in order to allow the identification of parameters in specified model. Where $\dot{L}_{x}, \dot{L}_{n}$ and $\dot{K}_{x}, \dot{K}_{n}$ are representation of changes in stock of labor and capital of both export and non-export sector and $F_{x}$ explains the positive externality effect of export sector on the output of non-export sector.

If we put equation (9) and (10) in equation (8) then we finally get following equation:

$$
\dot{Y}=F_{L} \dot{L}_{n}+F_{K} \dot{K}_{n}+F_{x} \dot{X}+G_{L} \dot{L}_{x} G_{L} \dot{K}_{x}
$$

Now putting the values of $G_{K}$ and $G_{L}$ in equation (11) then we get the following form of equation:

$$
\dot{Y}=F_{L} \dot{L}_{n}+F_{K} \dot{K}_{n}+F_{x} \dot{X}+(1+\delta) F_{L} \dot{L}_{x}+(1+\delta) F_{K} \dot{K}_{x}
$$

By simplifying it we gain:

$$
\begin{aligned}
& \dot{Y}=F_{L} \dot{L}_{n}+F_{K} \dot{K}_{n}+F_{x} \dot{X}+F_{L} \dot{L}_{x}+\delta F_{L} \dot{L}_{x}+F_{K} \dot{K}_{x}+\delta F_{K} \dot{K}_{x} \\
& \dot{Y}=F_{L}\left(\dot{L}_{n}+\dot{L}_{x}\right)+F_{K}\left(\dot{K}_{n}+\dot{K}_{x}\right)+\delta\left(F_{K} \dot{K}_{x}+F_{L} \dot{L}_{x}\right)+F_{x} \dot{X}
\end{aligned}
$$

By defining the total change in labor as $\dot{L}_{=} \dot{L}_{x}+\dot{L}_{n}$ and similarly the total change in capital stock as $\dot{K}=\dot{K}_{x}+\dot{K}_{n}$. So it can be written as:

$$
\dot{Y}=F_{L} \dot{L}+F_{K} \dot{K}+\delta\left(F_{K} \dot{K}_{x}+F_{L} \dot{L}_{x}\right)+F_{x} \dot{X}
$$

By using equation (6), (9) and (14) we get following derivation:

$$
\dot{Y}=F_{L} \dot{L}+F_{K} \dot{K}+\delta\left[\frac{G_{K}}{1+\delta}\left(\dot{K}_{x}\right)+\frac{G_{L}}{1+\delta}\left(\dot{L}_{x}\right)\right]+F_{x} \dot{X}
$$

By more simplifying:

$$
\dot{Y}=F_{L} \dot{L}+F_{K} \dot{K}+\frac{\delta}{1+\delta}\left[G_{K} \dot{K}_{x}+G_{L} \dot{L}_{x}\right]+F_{x} \dot{X}
$$


Pakistan Journal of Humanities and Social Sciences, 5(1), 2017

$$
\begin{aligned}
& \dot{Y}=F_{L} \dot{L}+F_{K} \dot{K}+\frac{\delta}{1+\delta}(\dot{X})+F_{x} \dot{X} \\
& \because \dot{X}=G_{L} \dot{L}_{x}+G_{K} \dot{K}_{x} \\
& \dot{Y}=F_{L} \dot{L}^{2}+F_{K} \dot{K}+\dot{X}\left(\frac{\delta}{1+\delta}+F_{x}\right)
\end{aligned}
$$

By dividing the equation (16) with $\mathrm{Y}$ and substituting $\alpha=F_{K}\left(\frac{K}{Y}\right), \beta=F_{L}\left(\frac{L}{Y}\right)$ and $\gamma=\left[\frac{\delta}{1+\delta}+F_{x}\right]$ we get following form of equation:

$$
\frac{\dot{Y}}{Y}=\alpha \frac{\dot{K}}{K}+\beta \frac{\dot{L}}{L}+\left[\frac{\delta}{1+\delta}+F_{x}\right]\left[\left(\frac{\dot{X}}{X}\right)\left(\frac{X}{Y}\right)\right]
$$

And its reduced form is as below:

$$
\frac{\dot{Y}}{Y}=\alpha \frac{\dot{K}}{K}+\beta \frac{\dot{L}}{L}+\gamma\left[\left(\frac{\dot{X}}{X}\right)\left(\frac{X}{Y}\right)\right]
$$

Where:

$$
\gamma=\left[\frac{\delta}{(1+\delta)}+F_{x}\right]
$$

Calculation of Social Marginal Productivity of investment in exports $\left(T M P K_{x}\right)$

$T M P K_{x}$ Is distinct as the total increment to GDP brought about by a marginal increase in capital allocated to the export sector i.e.

$$
\begin{aligned}
& T M P K_{x}=\frac{d Y}{d K_{x}}=\frac{\partial X}{\partial K_{x}}+\frac{\partial N}{\partial X} \frac{\partial X}{\partial K_{x}} \\
& T M P K_{x}=G_{K}+F_{x} G_{k} \\
& \frac{T M P K_{x}}{G_{k}}=1+F_{x}
\end{aligned}
$$

Recall equation (6)

$\frac{G_{K}}{F_{K}}=1+\delta$

Hence,

$$
1-\frac{F_{K}}{G_{K}}=\delta(1+\delta)
$$

By using equation (20) and (21):

$$
\left(T M P K_{x}-F_{K}\right) / G_{k}=F_{x}+\frac{\delta}{(1+\delta)}
$$




\section{External effect of export on non-export sector $\left(F_{x}\right)$}

So far we are not able to decompose the factor productivity differential $\gamma$ into its components. In order to identify the constant elasticity of export sector to effect the production of non-export sector. In this way we can find out the external effect of export sector on the production of non-export sector:

$$
N=F\left(K_{n}, L_{n}, X\right)
$$

In order to measure the constant elasticity of export sector:

$$
N=X^{\psi} \phi\left(K_{N}, L_{N}\right)
$$

Where $\psi$ is a parameter? By differentiating the equation (23) w.r.t $\mathrm{X}$ we get the following equation:

$$
F_{x}=\frac{\partial N}{\partial X}=\psi \frac{N}{X}
$$

Aside

$$
\psi \frac{N}{X}=\psi\left(\frac{N / Y}{X / Y}\right)
$$

Where

$$
\begin{aligned}
& N / Y=1-X / Y \\
& \psi \frac{N}{X}=\psi \frac{(1-X / Y)}{X / Y}=\frac{\psi}{X / Y}-\psi
\end{aligned}
$$

By using equation (17) and (24)

$$
\begin{aligned}
& \frac{\dot{Y}}{Y}=\alpha \frac{\dot{K}}{K}+\beta \frac{\dot{L}}{L}+\left[\frac{\delta}{(1+\delta)}+F_{x}\right]\left[\left(\frac{\dot{X}}{X}\right)\left(\frac{X}{Y}\right)\right] \\
& \frac{\dot{Y}}{Y}=\alpha \frac{\dot{K}}{K}+\beta \frac{\dot{L}}{L}+\left[\frac{\delta}{(1+\delta)}+\psi \frac{N}{X}\right]\left[\left(\frac{\dot{X}}{X}\right)\left(\frac{X}{Y}\right)\right] \\
& \frac{\dot{Y}}{Y}=\alpha \frac{\dot{K}}{K}+\beta \frac{\dot{L}}{L}+\left[\frac{\delta}{(1+\delta)}+\frac{\psi}{X / Y}-\psi\right]\left[\left(\frac{\dot{X}}{X}\right)\left(\frac{X}{Y}\right)\right] \\
& \frac{\dot{Y}}{Y}=\alpha \frac{\dot{K}}{K}+\beta \frac{\dot{L}}{L}+\left[\frac{\delta}{(1+\delta)}-\psi\right]\left[\left(\frac{\dot{X}}{X}\right)\left(\frac{X}{Y}\right)\right]+\psi \cdot \frac{Y}{X}\left[\left(\frac{\dot{X}}{X}\right)\left(\frac{X}{Y}\right)\right]
\end{aligned}
$$

And we get the following reduced form of equation:

$$
\frac{\dot{Y}}{Y}=\alpha \frac{\dot{K}}{K}+\beta \frac{\dot{L}}{L}+\left[\frac{\delta}{(1+\delta)}-\psi\right]\left(\frac{\dot{X}}{X}\right)\left(\frac{X}{Y}\right)+\psi\left(\frac{\dot{X}}{X}\right)
$$


Following the theoretical model, we express the export-led growth (ELG) in functional form as below:

$\mathrm{GDPG}=f$ (labor growth, capital growth, export growth)

To prove export-led growth (ELG) hypothesis we use labor growth rate, capital growth rate and export growth rate in our specified model. Economic growth is the depended variable as shown in above functional form.

$$
\dot{Y} / Y=f(\Delta L / L, \Delta K / K,(\Delta X / X)(X / Y)
$$

Where economic growth $(\dot{Y} / Y)$ is a dependent variable. While labor force growth ( $\Delta L / L)$, gross fixed capital formation $(\Delta K / K)$ and export growth $((\Delta X / X)(X / Y)$ are explanatory variables. The above equation shows the impact of growth of explanatory variables on economic growth.

As the equation (25) is as below:

$$
\frac{\dot{Y}}{Y}=\alpha \frac{\dot{K}}{K}+\beta \frac{\dot{L}}{L}+\left[\frac{\delta}{(1+\delta)}-\psi\right]\left(\frac{\dot{X}}{X}\right)\left(\frac{X}{Y}\right)+\psi\left(\frac{\dot{X}}{X}\right)
$$

Hence;

$$
\begin{aligned}
& T_{M P K_{x}}=F_{K}\left[1+\psi\left(\frac{1-x}{x}\right)\right](1+\delta) \\
& T M P K_{x}=\alpha\left[1+\psi\left(\frac{1-x}{x}\right)\right](1+\delta)
\end{aligned}
$$

Where $\mathrm{x}=$ share of exports in GDP.

Reduced form of equations:

$$
\begin{aligned}
& \frac{\dot{Y}}{Y}=\alpha \frac{\dot{K}}{K}+\beta \frac{\dot{L}}{L}+\gamma\left[\left(\frac{\dot{X}}{X}\right)\left(\frac{X}{Y}\right)\right] \\
& \frac{\dot{Y}}{Y}=\alpha \frac{\dot{K}}{K}+\beta \frac{\dot{L}}{L}+\left[\frac{\delta}{(1+\delta)}-\psi\right]\left(\frac{\dot{X}}{X}\right)\left(\frac{X}{Y}\right)+\psi\left(\frac{\dot{X}}{X}\right)
\end{aligned}
$$

Both the equations (17 and 25) are estimated by OLS in case of Pakistan and India

$$
\frac{\dot{Y}}{Y}=\alpha \frac{\dot{K}}{K}+\beta \frac{\dot{L}}{L}+\gamma\left[\left(\frac{\dot{X}}{X}\right)\left(\frac{X}{Y}\right)\right]+\varepsilon_{t}
$$

Where $\varepsilon_{t}$ is error term, it includes impact of all those variables which are not included into the specified model explicitly.

When external effect of export sector is included the equation will be as under: 


$$
\frac{\dot{Y}}{Y}=\alpha \frac{\dot{K}}{K}+\beta \frac{\dot{L}}{L}+\left[\frac{\delta}{(1+\delta)}-\psi\right]\left(\frac{\dot{X}}{X}\right)\left(\frac{X}{Y}\right)+\psi\left(\frac{\dot{X}}{X}\right)+v_{t}
$$

Where $v_{t}$ is error term, it also includes impact of all those variables which are not included into the specified model explicitly.

When we will apply OLS technique of estimation on above equations then results of specified variables may be positive or may be negative. The variable of labor force growth ( $\Delta L / L)$ may be positive or negative. Similarly, the next one variable is gross fixed capital formation $(\Delta K / K)$

It might have positive or negative relationship with economic growth. Finally the most vital variable in our specified model is export growth $(\Delta X / X)(X / Y)$ may have positive or negative relationship with economic growth. So, all these variables may have positive or negative relationship with economic growth in both cases of Pakistan and India.

To check the impact of explanatory variables labor force growth $(\Delta L / L)$, gross fixed capital formation $(\Delta K / K)$ and export growth $(\Delta X / X)(X / Y)$ on economic growth $\dot{Y} / Y$, following econometric technique is applied:

$$
\dot{Y} / Y=\beta_{1}(\Delta L / L)+\beta_{2}(\Delta K / K)+\beta_{3}(\Delta X / X)(X / Y)+\mu_{t}
$$

As it is intercept less model so intercept is not present in above econometric equation. It shows the total effect of export growth $(\Delta X / X)(X / Y)$ on economic growth.

If we include the external effect of export growth $(\Delta X / X)(X / Y)$ on the production of non-export sector then following econometric equation will be formed:

$$
\dot{Y} / Y=\beta_{1}(\Delta L / L)+\beta_{2}(\Delta K / K)+\beta_{3}(\Delta X / X)(X / Y)+\beta_{4}(\Delta X / X)+\mu_{t}
$$

Where $(\Delta X / X)$ shows the external effect of export sector on the output of non-export sector in case of both countries Pakistan and India. It shows that whether the increment in export sector of both countries Pakistan and India positively or negatively impact the output of non-export sector. So above econometric technique will measure the external effect of export sector along with the total effect of export growth on economic growth in case of both countries Pakistan and India? 


\section{Data and Methodology}

In this section, we will discuss the description of variables. We will also focus on the sources of data. The data used for specified variables are taken from different sources. It is briefly explained in a Table 2 below:

Table 2: Description of Variables

\begin{tabular}{|c|c|c|}
\hline Variables & Sources for Pakistan & Sources for India \\
\hline $\begin{array}{l}\text { GDP Growth Annual } \\
\text { percentage }\end{array}$ & World Development Indicators & World Development Indicators \\
\hline $\begin{array}{c}\text { Gross Fixed Capital Formation } \\
\text { Exports }\end{array}$ & $\begin{array}{c}\text { Handbook of Statistics on the } \\
\text { Pakistan Economy }\end{array}$ & \multirow{2}{*}{$\begin{array}{l}\text { Handbook of Statistics on the } \\
\text { Indian Economy }\end{array}$} \\
\hline Labor Force & $\begin{array}{c}\text { Pakistan Economic Survey } \\
\text { (various issues) }\end{array}$ & \\
\hline
\end{tabular}

Source: Authors' compilation

\section{A. Description of Variables}

$\dot{Y} / Y=\frac{\Delta Y}{Y}=$ Real GDP growth rate

$\dot{K} / K=\frac{\Delta K}{K}=$ Gross Fixes Capital Formation growth rate

$\dot{X} / X=\frac{\Delta X}{X}\left(\frac{X}{Y}\right)=$ Total size or total effect of Export Sector

$\dot{L} / L=\frac{\Delta L}{L}=$ Labor Force growth rate

$\delta=$ Relative input productivity index of export sector with respect to non-export sector

$\frac{\Delta X}{X}=$ Externalities of export sector on non-export sector

And $\mathrm{Y}=$ Real GDP growth in annual percentage

$\mathrm{L}=$ Labor Force total, growth rate

GFCF $=$ Gross Fixed Capital Formation (in annual percentage)

$\mathrm{X}=$ Exports of goods and services current (LCU)

To estimate the theoretical framework the ordinary least square (OLS) has been used.

\section{Results and Discussion}

\section{A. Unit Root Test}

In this section we will investigate the time series properties of all variables, economic growth, labor force growth, gross fixed capital formation growth, total effect of export and external effect of export in case of Pakistan and India. Firstly, as the variable economic growth $\Delta Y / Y$ is concerned then this variable is stationary at level and this variable has no unit 
root problem in case of both Pakistan and India. Secondly, labor force growth $(\Delta \mathrm{L} / \mathrm{L})$ is also stationary at level in case of both Pakistan and India. Thirdly the variable gross fixed capital formation growth $(\Delta K / K)$ is also stationary at level in case of Pakistan and India. This variable also has no problem of unit root. Fourthly, the next one variable is total effect of export $(\Delta X / X)(X / Y)$. It is also stationary at level. This variable also has no unit root problem. So it is also a stationary variable. Finally, the last one variable is external effect of export $(\Delta X / X)$ and it is also stationary at level and it has no unit root problem. It is also a stationary variable. So, results of unit root test mentioned in above Table for all variables support us to draw this conclusion that all included variables in our specified model are stationary at level and they don't have the problem of unit root. That's why we prefer to apply ordinary least square (OLS) technique for estimation. Then the results of OLS will be reliable to make conclusion about this study.

Table 3: Results of Unit Root Test

\begin{tabular}{|c|c|c|c|c|c|c|c|}
\hline \multicolumn{8}{|c|}{ Pakistan } \\
\hline Variables & None & lags & intercept & lags & $\begin{array}{c}\text { Intercept } \\
\text { and } \\
\text { Trend }\end{array}$ & Lags & Conclusion \\
\hline$\Delta Y / Y$ & -1.3897 & 0 & -4.9167 & 0 & -5.6042 & 0 & Stationary \\
\hline$\Delta \mathrm{L} / \mathrm{L}$ & -0.6562 & 0 & -9.0455 & 0 & -9.6006 & 0 & Stationary \\
\hline$\Delta K / K$ & -4.1256 & 0 & -5.0886 & 0 & -5.5628 & 0 & Stationary \\
\hline$(\Delta X / X)(X / Y)$ & -1.6346 & 2 & -6.5777 & 0 & -6.6317 & 0 & Stationary \\
\hline$(\Delta X / X)$ & -1.3515 & 2 & -6.6123 & 0 & -6.6845 & 0 & Stationary \\
\hline \multicolumn{8}{|c|}{ India } \\
\hline$\Delta Y / Y$ & -0.9088 & 1 & -6.4408 & 0 & -7.8905 & 0 & Stationary \\
\hline$\Delta \mathrm{L} / \mathrm{L}$ & -1.6599 & 1 & -3.0239 & 0 & -4.0993 & 0 & Stationary \\
\hline$\Delta K / K$ & -1.1510 & 0 & -6.0684 & 0 & -6.4202 & 0 & Stationary \\
\hline$(\Delta X / X)(X / Y)$ & -0.9218 & 1 & -2.0960 & 1 & -7.2070 & 0 & Stationary \\
\hline$(\Delta X / X)$ & -1.5558 & 1 & -5.8769 & 0 & -5.8000 & 0 & Stationary \\
\hline
\end{tabular}

Source: Authors' calculations

\section{B. Empirical Results for Total Effects of Export Sector}

In specified model there are four variables, in which Real GDP growth rate is depended variable. The labor force growth rate, gross fixed capital formation and export growth rate are explanatory variables.

We begin our analysis with the examination of first variable specified in the model is labor force growth $(\Delta \mathrm{L} / \mathrm{L})$. Its coefficient is positive and also significant both for the Pakistan and India. The value of regression coefficient of labor force growth for Pakistan is 0.26. Similarly, for India the value of regression coefficient is 0.59 . Various economic theories like 
Solow-Swan neo-classical growth model, Endogenous growth theory, Robert Barro's growth model are in the support of positive relationship between labor force growth and economic growth.

In fact, labor is major source for the country's economic prosperity and economic growth. It is a tool to increase the production and technological innovation. All those countries who invest in their people can create and improve human capital, which ultimately leads to economic prosperity and economic growth.

Our findings are according to the theories of economic growth. The positive association between labor force growth and economic growth implies that both countries (Pakistan and India) are diverting their resources towards education, health, training of people, vocational institutes and welfare of people. Our results are in accordance with other empirical studies that also suggest the positive association between labor force growth and economic growth [Huang and Mintz, 1991; Mueller and Atesoglu, 1993; Alexander, 1990, 1995].

Table 4: OLS Estimates of FEDER Model for Pakistan and India (Total Effects)

\begin{tabular}{|c|c|c|c|c|c|c|}
\hline & \multicolumn{7}{|c|}{ Dependent Variable: GDP Growth } \\
\cline { 2 - 7 } & \multicolumn{7}{|c|}{ India } \\
\hline Regressors & Coefficient & Std. Error & t-Statistic & Coefficient & Std. Error & t-Statistic \\
\hline$\Delta \mathbf{L} / \mathbf{L}$ & 0.2634 & 0.1076 & 2.4481 & 0.5908 & 0.2453 & 2.4081 \\
\hline$\Delta K / K$ & 0.2270 & 0.0617 & 3.6761 & 0.3290 & 0.0784 & 4.1924 \\
\hline$(\Delta X / X)(X / Y)$ & 1.21256 & 0.155070 & 7.819511 & 0.658032 & 0.228265 & 2.882758 \\
\hline \multicolumn{7}{|c|}{ Diagnostic Tests } \\
\hline DW stat & 1.8399 & & 3.0187 \\
\hline JB test & 5.4886 & \multicolumn{3}{c|}{} \\
\hline
\end{tabular}

Source: Authors' calculations

The second variable is gross fixed capital formation growth $(\Delta K / K)$. In this study the gross fixed capital formation growth is used as proxy for investment. The slope coefficient of this variable is positive and significant both for Pakistan and India. The value of regression coefficient of gross fixed capital formation growth for Pakistan is 0.23 . Similarly the value of regression coefficient for India is 0.32 . The positive sign of gross fixed capital formation growth for both countries show that Pakistan and India have built up efficacious infrastructure that has contribute to economic growth of both countries. Many different things concerning gross fixed capital formation like as building or increasing existing mill, purchase of transport instrumentality, workplace instrumentality, like computers, printers and machinery utilized in the productive method may result in economic process. Asian nation might receive advantages from the externalities of business infrastructure developed over the past decades. 
According to this positive and significant changes in GDP growth are due to growth of gross fixed capital formation. Some specific studies have also discovered a positive correlation between gross fixed capital formation and growth [See Jadoon, A, Rashid, H.A, \& Azeem, A. (2015). Shaheen, S. Ali, M.M, Kausar, A. \& Bashir, F. (2013), Dava, E. (2012). Mukherjee, P. \& Modak, K. C.].

The major variable of interest of this study is the export sector $(\Delta X / X)(X / Y)$. The regression coefficient of export growth is positive and significant. The variable export growth or total effect or size of export sector is decomposed into two parts; marginal productivities of factors of production in export sector are high than non-export sector and external effect of export sector on non-export sector. We observe that value of regression coefficient of export growth for both Pakistan and India is positive and significant. The value of regression coefficient of export sector for Pakistan is 1.21. Same value of regression coefficient of export sector for India is 0.66 .

Firstly, export sector is considered as catalyst for economic growth of any nation. Export sector enhances economic process of a rustic in sense that because of increase in exports, the demand and returns of things of production will increase leading an economy to growth in output. This is able to additionally increase the technological advancement and investment efforts.

Secondly, the export led growth (ELG) is based on comparative advantage is multipronged in its externalities leading to optimum utilization of resources. It may result an increase in total productivity of an economy. That may cause the economic growth due to export growth.

Thirdly, exports help to earn foreign exchange reserves. It also eases the pressure on the balance of payment (BOP). Then it is very beneficial to promote the imports of capital goods, machinery, advance technology and all those goods which are not available domestically. These all goods are imported through the foreign exchange reserves earn by exports; these all goods enhance the total output and that cause economic growth.

Fourthly, Exports also cause the research and development (R\&D). Exports are mostly operated by large size firms. They invest on research and development to invent the new and low cost methods of production. Through which availability of resources and factors of production might be easy and increase the output with low cost to fulfill the both domestic and foreign demand. As the total productivity increases, it results in economic growth through a proper channel. 
Fifthly, growth of exports has stimulating impact on the full issue productivity through its positive impact on higher rates of capital formation. Exports can be done only where a firm has large capacity to produce. So a firm hires more and more factors of production like as labor, capital and technology to enhance its output to meet with foreign demand along with domestic demand. It creates employment opportunities. That results in high level of income, high aggregate demand and more and more output to meet this demand. In this way exports also cause the economic growth.

Finally another indicator of export growth is learning effect that causes economic growth. As large size firms mostly operate the exports, so these firms face the learning effect. This effect may be face by managers, labors, technicians and other workers. They learn with the passage of time and their skills improve. So output of large size firms increases with the passage of time against the low cost. Higher the level of output causes the economic growth.

So our findings show the positive association between export growth and economic growth as other empirical studies [See Emery, 1967; Balassa, 1978, 1985; Feder, 1982; Jung and Marshall, 1985; Chow, 1987; Krueger, 1990; Shirazi and Manap, 2004; Konya and Singh, 2006; Siddiqui et al., 2008 and Rahman \& Shahbaz, 2011].

Now we are going to discuss the results of assay shown in higher than Table to examine the overall result of export sector on economy. So far as the explanatory power of model for Pakistan is shown by the value of $R^{2}$ is -0.27 . Similarly the explanatory power of model designed for India is given by the value of $\mathrm{R}^{2}$ is -0.018 .

\section{Empirical Results from Total, Externality and Relative Factor Productivity Effects}

This model specifies the total effect of export sector along with external effects and productivity differential both for Pakistan and India. The Real GDP growth is depended variable, while labor growth, gross fixed capital formation, export growth and external effect of exports are explanatory variables.

In Table 5, for the Pakistan the sign of coefficient of labor force growth $(\Delta \mathrm{L} / \mathrm{L})$ is positive and significant and value of regression coefficient is 0.28 . The sign of gross fixed capital formation growth $(\Delta K / K$ ) is also positive and value of its regression coefficient is 0.22 .

The variable of total effect of export sector $(\Delta X / X)(X / Y)$ is insignificant and having negative sign in case of Pakistan. But the sign of external effect of export $(\Delta X / X)$ on non-export sector is positive and it shows that export sector has positive externalities on non-export sector in case of Pakistan. Its regression coefficient is 0.21 . The result of 
productivity differential is negative in case of Pakistan. The value of its coefficient is -0.42 . So marginal productivities in export sector of Pakistan is not high than non-export sector.

Table 5: OLS based Results of Total, Externality and Relative Factor Productivity Effects

\begin{tabular}{|c|c|c|c|c|c|c|}
\hline \multirow{2}{*}{ Regressors } & Pakistan & & & India & & \\
\hline & Coefficient & Std. Error & t-Statistic & Coefficient & Std. Error & t-Statistic \\
\hline$\Delta \mathrm{L} / \mathrm{L}$ & 0.273528 & 0.105890 & 2.583137 & 0.165054 & 0.292923 & 0.563473 \\
\hline$\Delta K / K$ & 0.222107 & 0.060742 & 3.656568 & 0.289556 & 0.070753 & 4.092488 \\
\hline$(\Delta X / X)(X / Y)$ & -0.282933 & 0.971341 & 0.291281 & 0.610145 & 0.347101 & 1.757834 \\
\hline$(\Delta X / X)$ & 0.208428 & 0.133702 & 1.558907 & -0.022870 & 0.055182 & -0.414447 \\
\hline \multicolumn{7}{|c|}{ Diagnostic Tests } \\
\hline DW stat & \multicolumn{3}{|c|}{1.990149} & \multicolumn{3}{|c|}{2.469256} \\
\hline JB test & \multicolumn{3}{|c|}{4.585361} & \multicolumn{3}{|c|}{3.628866} \\
\hline $\begin{array}{r}\text { Productivity } \\
\text { differential }\end{array}$ & \multicolumn{3}{|c|}{-0.42} & \multicolumn{3}{|c|}{1.43} \\
\hline
\end{tabular}

Source: Authors' calculations

In case of Pakistan the explanatory power of model is given by value of $\mathrm{R}^{2}$ is -0.189 . There is no evidence of auto-correlation equally shown by the value of Durbin-Watson test. It is about 1.99 . The value of Jarque Berra test is greater than $1 \%$ so residuals are normally distributed.

Now we will discuss the model with total effect, external effect and productivity differential for India. For India the sign of labor force growth $(\Delta \mathrm{L} / \mathrm{L})$ is again positive and significant. The value of regression coefficient is 0.17 . The sign of gross fixed capital formation growth $(\Delta K / K)$ is positive and significant as before in Feder model. The value of regression coefficient is 0.29 . The regression coefficient of export sector $(\Delta X / X)(X / Y)$ is positive and also significant as before. The value of its regression coefficient is 0.61 . But the regression coefficient of external effect $(\Delta X / X)$ is negative and insignificant. Its regression coefficient is -0.02 . It shows the export sector of India has no positive externalities on nonexport sector. The value of productivity differential is 1.43 . Its coefficient is positive. So, marginal productivities are high in export sector than non-export sector.

In case of India, the explanatory power of model is given by the value of $R^{2}$ is 0.20 . The value of Jarque Berra test is 3.63 and it is greater than $1 \%$. So residuals are normally distributed. The value of Durbin-Watson test is 2.47 and shows that 


\section{Conclusion and Policy Recommendations}

The main purpose this study is to investigate the productivity, external effect of export on economic growth by utilizing Feder model developed by Feder (1982) in case of Pakistan and India. This study is based on time series data from 1972 to 2014 for Pakistan and India. Data for all variables are extracted from world development indicators (WDI), Pakistan Economic Survey, Handbook of Statistics on the Pakistan Economy and Handbook of Statistics on the Indian Economy. This section has been set to summarize the findings of the study and to give policy implications.

Furthermore, the empirical evidence of this study gives us consent to draw some conclusions on this model through which export has impact on economic growth of both countries Pakistan and India. It is concluded that both the countries Pakistan and India have great benefits from trade liberalization on export side through the better allocation of resources like labor and capital etc. Which is itself leads the economy to efficiency through competition in international market. In case of Pakistan, total effect of export sector on economy is remarkable and its external effect is positive on non-export sector to enhance economic growth. Marginal productivities of factors of production indulge in export sector are not high than non-export sector in case of Pakistan. But in case of India total effect of export on economic growth is also positive. Export growth in India causes for leading economy to high growth rate. Marginal productivities of export sector are high than nonexport sector in India. It means factors of production indulge in export sector are more productive than non-export sector. But external effect of export on non-export sector is not remarkable in India according to empirical evidences. The impact of labor growth is also positive and remarkable in case of both countries Pakistan and India. It means growth in labor force has positive impact on economic growth. Similarly the connection between gross fixed capital formation growth and economic process of each countries Asian country and Asian country is additionally vital and positive. It concludes that the growth of gross fixed capital formation also leads the economy to economic growth in case of Pakistan and India.

The findings are such that marginal productivities of factors of production are high in export sector than non-export sector in case of both countries.

- Firstly, outward-looking policy is more beneficial to transfer the resources from nonexport sector to export sector. It will result in high economic growth in both countries Pakistan and India. 
Fatima Subhani, Atif Yaseen, Bashir Ahemd Khan, Anees Ayyub

- Secondly, export promotion policies, export oriented policies should be adopted by both countries to lead to economic growth.

- It is also suggested that both countries should move towards trade liberalization to boost up the export growth so that economic growth also increases. 
Pakistan Journal of Humanities and Social Sciences, 5(1), 2017

\section{References}

Aurangzeb, A. Z. (2006). Exports, Productivity and Economic Growth in Pakistan: A Time Series Analysis. Lahore Journal of Economics, 11(1), 1-18.

Awokuse, T. O. (2003). Is the export-led growth hypothesis valid for Canada? Canadian Journal of Economics/Revue comedienne d'économique, 36(1), 126-136.

Azam, M. (2011). Exports and economic growth in Pakistan: An empirical analysis. Journal of Managerial Sciences, 5(2), 159-166.

Chow, P. C. (1987). Causality between export growth and industrial development: empirical evidence from the NICs. Journal of development Economics, 26(1), 55-63.

Din, M. U. (2004). Exports, imports, and economic growth in South Asia: Evidence using a multivariate time-series framework. The Pakistan development review, 105-124.

Ekanayake, E. M. (1999). Exports and economic growth in Asian developing countries: Cointegration and error-correction models. Journal of Economic Development, 24(2), 43-56.

Emery, R. F. (1967). The Relation of Exports and Economic Growth*. Kyklos, 20(4), 470486.

Eusuf, M. A., \& Ahmed, M. (2007). Causality between export and growth: Evidence from South Asian Countries. MPRA Paper, (21027).

Feder, G. (1983). On exports and economic growth. Journal of development economics, 12(1), 59-73.

Hameed, A., Chaudhary, M. A., Khan, K. Y., \& Hasan, L. (2005). The Growth Impact of Exports in South Asian Countries. The Pakistan Development Review, 901-919.

Jung, W. S., \& Marshall, P. J. (1985). Exports, growth and causality in developing countries. Journal of development economics, 18(1), 1-12.

Khan, A. H., Malik, A., Hasan, L., \& Tahir, R. (1995). Exports, Growth and Causality: An Application of Co-integration and Error-correction modeling. The Pakistan Development Review, 34(4), 1001-1012...

Mehdi, S., \& Reza, M. (2011). A study examining the effect of export growth in Iran. International Business and Management, 3(1), 92-98.

Pandey, A. K. (2006). Export and economic growth in India: Causal interpretation.

Quddus, M. A., Saeed, I., \& Asghar, Z. (2005). An Analysis of Exports and Growth in Pakistan. The Pakistan Development Review, 921-937. 
Ridzuan, A. R., Noor, A. H. M., \& Ahmed, E. M. ASEAN4 prospective of export-led economic growth.

Saleem, A., \& Sial, M. H. (2015). Exports-Growth Nexus in Pakistan: Cointegration and Causality Analysis. Pakistan Economic and Social Review, 53(1), 17.

Shihab, R. A., Soufan, T., \& Abdul-Khaliq, S. (2014). The Causal Relationship between Exports and Economic Growth in Jordan. International Journal of Business and Social Science, 5(3).

Shirazi, N. S., \& Manap, T. A. A. (2005). Export-led growth hypothesis: further econometric evidence from South Asia. Developing Economies, 43(4), 472-488.

Shirazi, Nasim Shah, Turkhan Ali Abdul Manap, and Musleh-ud Din. (2004). Exports and economic growth nexus: The case of Pakistan. The Pakistan Development Review, 563-581.

Siddique, M. A. B., \& Selvanathan, E. A. (1999). Export Performance and Economic Growth: Co-integration and causality analysis for Malaysia, 1966-96. Department of Economics, University of Western Australia.

Siddiqui, S., Zehra, S., Majeed, S., \& Butt, M. S. (2008). Export-led growth hypothesis in Pakistan: A reinvestigation using the bounds test. Lahore Journal of Economics, 13(2), 59-80. 